\title{
Bachelor of Education
}

National Cancer Institute

\section{Source}

National Cancer Institute. Bachelor of Education. NCI Thesaurus. Code C71348.

A bachelor's degree in education awarded to students seeking training to become teachers in primary and secondary schools. 